\title{
A Revised Structural Dimensionality of the Attributions about Poverty and Wealth
}

\section{Scales}

Dimensionalidad estructural revisada de las escalas de atribuciones sobre la pobreza y

\section{la riqueza}

Mario Sainz, Juan Diego García-Castro, Gloria Jiménez-Moya, \& Roberto M. Lobato*

Mario Sainz: Escuela de Psicología, Pontificia Universidad Católica de Chile, Santiago de Chile, Chile. https://orcid.org/0000-0002-2048-5872

Juan Diego García-Castro: Centro de Estudios de Conflicto y Cohesión Social, Santiago de Chile, Chile, and Universidad de Costa Rica, Sede de Occidente, San Ramón, Costa Rica. https://orcid.org/0000-0002-9662-6547

Gloria Jiménez-Moya: Escuela de Psicología, Pontificia Universidad Católica de Chile, Santiago de Chile, Chile. https://orcid.org/0000-0002-5927-6437

Roberto M. Lobato: Department of Psychology, Marbella International University Centre, Marbella, Spain. https://orcid.org/0000-0003-4152-7020

*Corresponding author: Roberto M. Lobato, Marbella International University Centre, Avenida Don Jaime de Mora y Aragón, s/n, Marbella 29601, Spain.

Email: romulobato@gmail.com

Phone: (+34) 619005016

\section{Statements}

Data availability statement: Databases, analysis scripts, and supplemental materials can be found online: https://osf.io/w7asu/?view only=8ea6d8cec0314f129d0f7464e 5cbdc1d

Conflict of interest statement: Authors do not have any conflict of interest. 
POVERTY AND WEALTH ATTRIBUTION SCALES

Ethical statement: These studies were approved by the ethical committee of the Pontificia Católica Universidad de Chile (ID 200414006).

Informed consent: Informed consent was obtained from all individual participants included in the study.

Funding: This research was funded by Agencia Nacional de Investigación y Desarrollo ANID - through the program FONDECYT Postdoctorado 2020 [Project number 3200031]. Acknowledgments: We acknowledge support from the Centre for Social Conflict and Cohesion Studies - COES (ANID/FONDAP/15130009). 
POVERTY AND WEALTH ATTRIBUTION SCALES

\section{A Revised Structural Dimensionality of the Attributions about Poverty and Wealth}

\section{Scales}

People's understanding of the causes of poverty and wealth is an essential trigger for how they interact with these social groups. However, the existing measures that capture these phenomena have several limitations. Therefore, we revised the factorial structure of the poverty and wealth attribution scales to create a unified scale. We back-translated the original items, conducted exploratory and confirmatory analyses, restructured the scale's factors, and related them with other covariates to test its validity. Our results indicate that these scales differentiated between internal and external attributions, demonstrating that the new factorial structure has a better fit than the original structure has.

Keywords: attributions, poverty, wealth, scales, psychometrics 
POVERTY AND WEALTH ATTRIBUTION SCALES

Dimensionalidad estructural revisada de las escalas de atribuciones sobre la pobreza y la riqueza

La comprensión de las causas de la pobreza y la riqueza por parte de las personas es un factor desencadenante esencial de su interacción con estos grupos sociales. Sin embargo, las medidas existentes que tratan de evaluar estos fenómenos tienen varias limitaciones. Por ello, se presenta una revisión de la estructura factorial de las escalas de atribución de pobreza y riqueza para crear una escala unificada. Los ítems originales fueron traducidos mediante una traducción inversa, se realizaron análisis exploratorios y confirmatorios, se reestructuraron los factores de la escala y se relacionaron con otras covariables para probar su validez. Los resultados indican que estas escalas diferencian entre atribuciones internas y externas, demostrando que la nueva estructura factorial tiene un mejor ajuste que la estructura original. Palabras clave: atribuciones, pobreza, riqueza, escala, psicometría 
POVERTY AND WEALTH ATTRIBUTION SCALES

The attribution process has a relevant influence on how people perceive and understand individual and group circumstances (Heider, 1958). This is especially relevant when individuals attempt to understand social outcomes such as the poverty of certain groups and the affluence of others (Bullock et al., 2003; Cozzarelli et al., 2001; Weiner et al., 2011). Within this context, people develop lay theories concerning the reasons behind society's increasing poverty rates or the hoarding of wealth by a few (Lepianka et al., 2009).

Specifically, people tend to blame poor people for their poverty by attributing their negative social outcomes to a lack of effort or motivation (i.e., internal attributions). At the same time, they tend to underestimate the discrimination or lack of opportunities (i.e., external attributions) that poor people face in their daily lives (e.g., Cozzarelli et al., 2001; Feagin, 1975; Furnham, 1982). Further, people's understanding of wealth usually relies on the belief that rich people are highly motivated or possess better capabilities (i.e., internal attributions). People hold this belief while failing to recognise how having access to education or resources as a consequence of the family heritage (i.e., external attributions) is among the greatest sources of these groups' wealth (e.g., Bullock et al., 2003; Bullock \& Fernald, 2005; Furnham, 1982).

Due to the relevance of the attributional process, the present study is aimed at reviewing the factorial structure of poverty (Cozzarelli et al., 2001) and wealth attribution scales (Bullock et al., 2003), as well as adapting and verifying the validity of these scales among the Spanish-speaking population. This adapted instrument will constitute an adequate tool for expanding research on this topic.

\section{Causal Attributions About Poverty and Wealth}

The attributional process has been studied thoroughly in the literature. The first models were aimed at understanding people's inferences about the factors that lead individuals or the self to act, feel, or think in a certain way in specific situations (Heider, 
POVERTY AND WEALTH ATTRIBUTION SCALES

1958; Kelley, 1967). This attributional process has been applied to people's understanding of socioeconomic differences. Specifically, early research on this issue proposed various factors to which people could attribute a group's deprived position (Feagin, 1972). These initial efforts were mainly focused on understanding poverty, as it was considered a more prominent social issue than the hoarding of wealth during these previous decades. However, previous studies have been inconsistent in terms of the scales proposed for capturing attributional processes, and they suggested different factors and different scales in mainly Englishspeaking countries during the previous decades.

Specifically, concerning attributions about the causes of poverty, previous studies consistently differentiated between and found empirical support for the distinction between internal and external sources of poverty. In this sense, internal attributions highlight individuals' responsibility for their economic standing, whereas external attributions contribute to recognising the contributions of contextual or third-party actors to the individual's financial standing. This implies that people's attributions about poverty depend to a greater extent on where they assign responsibility, which is in line with the original literature on attribution processes (i.e., locus; Heider, 1958). In particular, people understand that poverty might be driven by individuals' behaviour or decisions regarding their deprived circumstances (e.g., lack of effort, being lazy; Cozzarelli et al., 2001). Because of attributional bias (i.e., fundamental attribution error; Ross, 1977), people are more willing to interpret poverty as having internal causes rather than to other factors such as external attributions. In this sense, external factors are the contextual or societal variables that lead people to struggle in poverty (e.g., discrimination, low wages, lack of proper education). These factors, which are not under the control of the individuals facing scarcity, have a direct influence on the perpetuation of poverty along generational lines. The recognition of these external factors as triggers of poverty is associated with more positive attitudes towards poor 


\section{POVERTY AND WEALTH ATTRIBUTION SCALES}

people or increased willingness to support redistributive policies (Cozzarelli et al., 2001; Sainz, Martínez, et al., 2020). In addition, previous research on this topic highlights the existence of alternative factors in the attributional processes. This is the case for fatalistic attributions such as having bad luck in life or having physical handicaps (Feagin, 1972), or cultural contributions such as being born into poverty or the breakdown of the nuclear family (Cozzarelli et al., 2001). These complementary dimensions are less empirically consistent and often include a set of items that can be classified in the aforementioned previous dimensions (Castillo, 2018; Cozzarelli et al., 2001; Osborne \& Weiner, 2015).

Previous research on the causes of wealth has received less attention, and the literature contains less empirical evidence. The existing literature suggests that lay theories about the causes of wealth also differentiate among various factors or sources of wealth. For instance, Forgas et al. (1982) proposed a model that differentiates between the well-known dimensions of internal or individual attributions (e.g., being born with good business sense) and external or social attributions (e.g., a taxation system that favours the rich), along with factors associated with family background (e.g., inherited wealth from relatives) and luck or risk-taking (e.g., winning the lottery). Further, Bullock et al. (2003) proposed an alternative factorial model that differentiated among wealth sources related to perseverance/ambition (e.g., being very intelligent), corruption/pull (e.g., networking and having the right “contacts"), fatalism/luck (e.g., being in the right place at the right time), and privilege (e.g., inherited wealth from relatives). Both of these attributional models of wealth have commonalities with the existing attribution models for poverty in that they rely on some factors that can be understood as internal (e.g., perseverance) and others that can be considered external (e.g., luck or privilege). Further, as in poverty, the additional factors or sources (e.g., privilege, bad luck) are less empirically consistent. They often represent a mix 
POVERTY AND WEALTH ATTRIBUTION SCALES

of internal and external attributions that cannot be mutually exclusive (Hunt, 2004; Sainz, Martínez, Rodríguez-Bailón et al., 2019).

\section{Correlates and Consequences of Causal Attributions About Poverty and Wealth}

The attributional processes for the understanding of poverty and wealth have commonalities in terms of how people identify the sources of individuals' economic standing within internal or external factors. However, there are opposite consequences for perceiving poverty or wealth as resulting from internal or external factors. In this sense, higher endorsement of internal attributions about poverty than external attributions leads people to help poor people less, blame them for their poverty more, and favour the rejection of redistribution policies aimed at reducing socioeconomic differences (Bullock et al., 2003; Cozzarelli et al., 2001; Sainz, Martínez, et al., 2020; Tagler \& Cozzarelli; 2013; Weiner et al., 2011). In contrast, internal attributions about wealth are related to more positive attitudes towards the rich compared to external attributions, leading individuals to praise wealthy people for their advantaged position and reject the implementation of redistribution policies or a progressive taxation system (Alesina \& La Ferrara, 2005; Bullock \& Fernald, 2005; Sainz, Martínez, Rodríguez-Bailón et al., 2019).

Certain variables usually drive these attributional processes. This is the case, for instance, for people's adherence to political conservatism, social dominance orientation, or justification of system ideologies positively associated with internal causes of poverty and wealth and negatively associated with external causes of poverty and wealth (Bobbio et al., 2010; Furnham, 1983; Kluegel \& Smith, 1986; Robinson, 2009). In addition, individual socioeconomic status (SES) can also play a role in adherence to internal attributions rather than external attributions. In this sense, high-SES individuals engage more easily in attributions that justify their advantaged position (i.e., more internal and less external), 


\section{POVERTY AND WEALTH ATTRIBUTION SCALES}

whereas low-SES individuals favour external attributions about their wealth rather than external attributions (Bullock et al., 1999; Nasser, 2017).

In short, the attributional process can potentially bias the understanding of poverty and wealth. Thus, it might influence how people behave or what they expect from poor and wealthy groups in their society. However, the existing measures that capture these phenomena have several limitations. Firstly, there is inconsistency and a lack of empirical support for certain subfactors, such as the cultural (Cozzarelli et al., 2001) and fatalist (Bullock et al., 2003) elements of the poverty and wealth attribution scales. Secondly, previous attempts to measure attributions about poverty and wealth have been focused on analysing these processes independently without proposing a unified scale that could evaluate the approaches simultaneously. Thirdly, some items originally included in previous scales (e.g., "the breakdown of the nuclear family"; Cozzarelli et al., 2001) could lack relevance in contemporary society. Lastly, most of the previous research that used the scales mentioned above was conducted in Western, educated, industrialised, rich, and democratic (WEIRD) populations. No formal attempts to explore the factorial structure of both scales simultaneously with non-WEIRD samples have been made before. Therefore, based on these limitations, we aim to revise the factorial structure of the poverty and wealth attribution scales to create a unified and updated scale to measure this process among Spanish-speaking populations.

\section{Overview}

People's attributions about the causes of poverty and wealth affect how they understand and justify socioeconomic differences. However, the existing scales have several limitations. Due to the role of this attributional process on the maintenance of the status quo, it is essential to expand the research in this area. To do so, we aimed to adapt and validate poverty (Cozzarelli et al., 2001) and wealth (Bullock et al., 2003) attribution scales with 


\section{POVERTY AND WEALTH ATTRIBUTION SCALES}

Spanish speakers. We started by back-translating items initially developed for English speakers to determine whether they were adequate for the study's context. Then, we performed exploratory and confirmatory analyses to check the reliability and restructuring of the scale's factor. We conducted these analyses with the problems mentioned above using the factorial structure of the original scales. We ended by providing correlations of the scales' subfactors with other related processes in the literature. Databases, analysis scripts, and supplemental materials can be found online:

https://osf.io/w7asu/?view_only=8ea6d8cec0314f129d0f7464e5cbdc1d

\section{Method}

\section{Adaptation of Items from the Poverty and Wealth Attribution Scales to Spanish}

We used the original items for the poverty attribution scale, which included 18 items along three subdimensions: internal (e.g., "lack of effort and laziness by the poor"), external (e.g., "prejudice and discrimination in hiring"), and cultural/structural (e.g., "being born into poverty") attributions (Cozzarelli et al., 2001). We also considered the wealth attribution scale, which included 22 items within four dimensions or causes of wealth:

perseverance/ambition (e.g., "hard work"), corruption/pull (e.g., "ruthlessness"), fatalism/luck (e.g., "winning the lottery”), and privilege/inheritance (e.g., "attending elite universities"; Bullock et al., 2003). Both scales were translated from the source language (English) into the target language (Spanish) by two translators (male and female) with mastery of both languages. Later, the authors compared and discussed both translations to reach consensus on each item. Thereafter, two independent translators (female and male) back-translated the items from Spanish into English. This back-translated version was compared with the original scale to ensure the quality of the translation process (Hambleton, 2005). 
POVERTY AND WEALTH ATTRIBUTION SCALES

The Spanish version of the items from both scales was then evaluated using expert judgment (Carretero-Dios \& Pérez, 2007). Notably, four scholars with expertise in social psychology and scale construction considered the following: (a) the wording of each item, (b) the representation of the construct the items measured, (c) the subfactor to which each item ought to belong, and (d) alternative versions of each item when necessary. During this process, the experts noted that the items "the breakdown of the nuclear family" (poverty attribution scale) and "strong trade unions that lobby for higher wages for workers" (wealth attribution scale) barely applied to the current circumstances or the specific context to which the instrument was to be adapted. Thus, these items were excluded from the Spanish version of the scales. Final modifications were made to the other items based on the experts' evaluation. The items selected after performing the analyses are presented in Table 1 (see the supplemental materials for the specific details of the translations and expert judgment process).

\section{[Insert Table 1]}

\section{Participants and Procedure}

We recruited participants using Prolific Academic, a professional recruiting service. Each participant was compensated with $1 £$ for a four-minute study, which was conducted among Mexican participants. This was because Mexico has a high level of economic inequality (CONEVAL, 2018), making socioeconomic differences salient in social interactions and creating an ideal context for attributional processes.

The total sample consisted of 523 participants (54.3\% male, $45.3 \%$ female, and $0.4 \%$ other; $M_{\text {age }}=25.31, S D=9.36$ ), all of whom were Mexican citizens, native speakers of Spanish, and currently residing in Mexico. We randomly split the sample into two subsamples to perform the exploratory and confirmatory analyses. The first subsample included 255 participants $\left(51.4 \%\right.$ male and $48.6 \%$ female; $\left.M_{\text {age }}=25.21, S D=8.74\right)$, and the 
POVERTY AND WEALTH ATTRIBUTION SCALES

second subsample included 268 participants (42.2\% male, $57.1 \%$ female, and $0.7 \%$ other; $\left.M_{\mathrm{age}}=25.40, S D=9.92\right)$. Once participants agreed to participate, they were presented with the following scales.

\section{Poverty Attribution Scale}

To measure participants' attributions about poverty, we included the 17 items adapted to Spanish speakers (see the supplemental materials for full details). The original scale developed by Cozzarelli et al. (2001) differentiated among three attributional factors: internal (e.g., "lack of effort and laziness by the poor"), external (e.g., "prejudice and discrimination in hiring”), and cultural/structural (e.g., "being born into poverty") causes of poverty. Participants were asked to rate the extent to which each item represents a possible factor that causes poverty. Answers ranged from 1 (not at all) to 7 (completely).

\section{Wealth Attribution Scale}

To measure participants' attributions about wealth, we included the 21 items adapted to Spanish speakers (see the supplemental materials for full details). The original scale (Bullock et al., 2003; Bullock \& Fernald, 2005) differentiated among four attributional factors: perseverance/ambition (e.g., "ability, hard work”), corruption/pull (e.g., "ruthlessness, networking”), fatalism/luck (e.g., "winning the lottery"), and privilege/inheritance (e.g., "attending elite universities"). Participants were asked to rate the extent to which each item represents a possible factor that causes wealth. Answers ranged from 1 (not at all) to 7 (completely).

\section{Social Dominance Orientation}

We included the eighth item's social dominance orientation scale (e.g., "Some groups of people are simply inferior to other groups," $\alpha=.81 / 75$; Ho et al., 2015). Answers ranged from 1 (completely disagree) to 7 (completely agree).

\section{System Justification}


POVERTY AND WEALTH ATTRIBUTION SCALES

We used the Spanish version of the system justification scale (seven items, e.g., "If people work hard, they almost always get what they deserve;" $\alpha=.85 / 85$ ) from Jaume et al. (2012). Answers ranged from 1 (completely disagree) to 7 (completely agree).

\section{Political Orientation}

Participants reported their political orientation by answering a single item for which answers ranged from 1 (extreme left) to 7 (extreme right; Piurko et al., 2011). Support for Redistribution Policies

We included four items aimed at measuring the support of redistribution actions promoted by the government (e.g., "The government should distribute wealth through large taxes on the wealthy;" $\alpha=.80 / 76$; adapted from Dawtry et al., 2015). Answers ranged from 1 (completely disagree) to 7 (completely agree).

\section{Subjective Socioeconomic Status}

Participants located themselves and their families on a ten-rung ladder representing the socioeconomic strata within the society (MacArthur ladder; Adler et al., 2000). Answers ranged from 1 (low SES) to 10 (high SES).

\section{Objective Socioeconomic Status}

Participants reported their monthly household net income and the number of individuals living in their household. We divided income by the number of household members to compute the objective SES score (Kraus \& Keltner, 2009). The average reported household income was MXN10,457 (around \$523).

Finally, participants reported their demographic information (gender, age, nationality, and language) and were thanked for their participation.

\section{Results}

\section{Exploratory Factor Analyses}


POVERTY AND WEALTH ATTRIBUTION SCALES

First, we conducted an exploratory factor analysis (EFA) with the poverty attribution scale using the first random subsample. We used a listwise method to address missing data because no more than $1 \%$ of data were missing for any item in the scale. Next, we employed the Kaiser-Meyer-Olkin (KMO) sample adequacy index and Bartlett's sphericity test. The KMO index score was .84, and Bartlett's test of sphericity was statistically significant $\left(\chi^{2}(136)=1642.06, p<.001\right)$, suggesting that the factor analysis was viable. Parallel analysis with the Watking program (2000) using 100 replications in simulation endorsed a two-factor solution. Thus, we computed an EFA using the maximum likelihood procedure with Oblimin rotation because we expected the factors to have a certain relationship with each other. The psychometric properties and factor loadings are presented in Table 2.

\section{[Insert Table 2]}

The resulting factor structure comprised two factors that explained $40.59 \%$ of the total variance. Regarding the loadings, the EFA showed a different grouping pattern than in the original scale. Furthermore, some items presented psychometric properties that did not conform to our expectations. Therefore, following common recommendations (Tabachnick \& Fidell, 2013), we removed the items that did not meet a minimum inclusion criteria. We retained items that (a) had coefficients exceeding 0.40 on the target factor, (b) loaded at least twice as strongly on the target factor as on the next highest loading factor, (c) did not load more than 0.30 on multiple factors, and (d) had communalities exceeding 0.20 . We were left with a pool of 11 items that loaded onto two factors, and we excluded Items 2, 6, 7, 14, 15, and 17. The internal subfactor presented a Cronbach's alpha of .89, and the external subfactor had a score of .79 .

Next, we conducted another EFA with the wealth attribution scale using the same subsample. Again, a KMO index of .88 and Bartlett sphericity test $\left(\chi^{2}(210)=2181.34\right.$, $p<.001)$ supported the EFA's validity. Parallel analysis with the Watking program (2000) 
POVERTY AND WEALTH ATTRIBUTION SCALES

using 100 replications in simulation supported a two-factor solution. Therefore, an EFA was computed using the maximum likelihood procedure with Oblimin rotation. The psychometric properties and factor loadings are presented in Table 3.

\section{[Insert Table 3]}

This time, the resulting factor structure comprised two factors that explained $39.69 \%$ of the total variance. The EFA showed a different grouping pattern than in the original scale, and some items presented psychometric properties that did not conform to our expectations. Thus, we removed those items that did not meet a minimum inclusion criteria, following the same recommendations as in the previous study (Child, 2006; Tabachnick \& Fidell, 2013). Consequently, we excluded Items $3,8,9,10,11,16,17$, and 20 . Thereafter, we found that the new two-factor structure did not conform to the original dimensions. Looking for similarities with the other scale and reviewing how the items were written, we found that the first factor corresponded to internal attributions, and the second corresponded to external attributions. Accordingly, the internal subfactor presented a Cronbach's alpha of .91, and the external factor had a score of .79.

\section{Confirmatory Factor Analyses}

After confirming that a two-factor structure was more appropriate for each of the scales, we decided to test the factorial fit of these structures using the second random subsample. Thus, we performed confirmatory factor analyses (CFA) to test different models. The first corresponded to the scales' original structure, whereas the second corresponded to the two-factor structure found in the EFAs. Given that the multivariate normality using Mardia's normalised coefficients showed multivariate kurtosis (374.78 for the poverty attribution scale and 571.08 for the wealth attribution scale), we decided to test the two models using the maximum likelihood estimator with robust estimation (Satorra-Bentler 
POVERTY AND WEALTH ATTRIBUTION SCALES

scaling corrections; Satorra \& Bentler, 2001). The lavaan R package was used to estimate the models (Rosseel, 2012), the fit statistics for both scales.

The results showed a better fit for the two-factor solutions in both scales in the case of the attributions about poverty: three factors fit $\left(\chi^{2}{ }_{(116)}=382.05, p<.001 ; \mathrm{CFI}=.81\right.$; TLI $=$ .77 ; RMSEA $[90 \% \mathrm{CI}]=.10[.09, .11] ; \mathrm{SRMR}=.12 ; \mathrm{AIC}=16727.49) ;$ two factors fit $\left(\chi^{2}(43)\right.$ $=87.94, p<.001 ; \mathrm{CFI}=.96 ; \mathrm{TLI}=.94 ; \mathrm{RMSEA}[90 \% \mathrm{CI}]=.07[.05, .09] ; \mathrm{SRMR}=.05 ;$ $\mathrm{AIC}=10351.83)$. But also, in the attributions about wealth: four factors fit $\left(\chi_{(183)}^{2}=422.68, p\right.$ $<.001 ; \mathrm{CFI}=.85 ; \mathrm{TLI}=.83 ; \mathrm{RMSEA}[90 \% \mathrm{CI}]=.08[.07, .09] ; \mathrm{SRMR}=.09 ; \mathrm{AIC}=$ 19229.66); two factors fit $\left(\chi^{2}{ }_{(64)}=140.46, p<.001 ;\right.$ CFI $=.93 ;$ TLI $=.91 ;$ RMSEA $[90 \% \mathrm{CI}]$ $=.08[.06, .09] ; \mathrm{SRMR}=.07 ; \mathrm{AIC}=11405.69)$. Further, an ANOVA confirmed that there were statistically significant differences between the original model and the two-factor model for the poverty attribution scale $\left(\Delta \chi^{2}=296.32, p<.001\right)$ and for the wealth attribution scale $\left(\Delta \chi^{2}=282.79, p<.001\right)$. Finally, Cronbach's alpha was calculated to check internal reliability. For the poverty attribution scale, the internal subfactor presented a Cronbach's alpha of .88, and the external factor had a score of .80. For the wealth attribution scale, the internal subfactor showed a Cronbach's alpha of .90, and the external factor had a score of .75 .

\section{Evidence of Convergent Validity}

Using the new two-factor factor structure for each scale, we tested correlations with other variables for convergent validity. We expected positive relationships between internal attributions and ideological variables and negative relationships with external attributions. Further, as previous research has shown, we also expected a negative relationship between internal attributions and support for redistribution policies and positive relationships with external attributions. Finally, we expected participants' SES to be positively related to 


\section{POVERTY AND WEALTH ATTRIBUTION SCALES}

internal attributions and negatively related to external attributions. The descriptive statistics and Pearson's bivariate correlations are presented in Table 4.

\section{[Insert Table 4]}

As we expected, the relationships between the subfactors within each scale were negative. In contrast, the relationship between internal attributions towards poverty and wealth was positively related, as were external attributions. Likewise, the scales' subfactors were associated with the ideological variables: higher ascription of social dominance orientation, system justification, or right-wing political orientation related positively to internal attributions and related negatively to external attributions. Further, the same pattern of results can be applied to redistribution policies. Finally, participants' SES did not relate consistently to the scales' subjective or objective subfactors. Uniquely, subjective SES was positively associated with internal attributions about wealth.

\section{Discussion}

In this study, we aimed to revise the factorial structure of existing poverty (Cozzarelli et al., 2001) and wealth (Bullock et al., 2003) attribution scales. These scales did not provide a consistent factorial structure. Some of their items lacked relevance in today's society or were designed uniquely for English-speaking participants. Thus, we adapted them to address some of these limitations and to provide a revised and unified factorial structure for these scales among Spanish-speaking participants.

Our results indicate that, among Spanish speakers, the poverty and wealth attribution scales differentiate among two negatively related factors that can be equated to internal and external attributions about their respective targets (i.e., poor and rich groups). This scales' emergent factorial structure was identified in the EFA, in which several items from the original scales were excluded due to their poor psychometric properties. This highlights how previous scales included items that were not ascribed to internal or external attributions but 


\section{POVERTY AND WEALTH ATTRIBUTION SCALES}

that saturated both dimensions simultaneously. Further, the CFA showed that the alternative factorial structure (i.e., two-factor scales) had a better fit than the instruments' original factorial structure, confirming that the simplified factor structure is adequate to measure the attributional process in this context with a Spanish speaking sample.

In addition, the scales that we included to test the validity of the revised version of the poverty and wealth attribution scales showed the expected pattern of results. Participants' adherence to ideological variables that favoured maintaining the status quo related positively to internal attributions and negatively to external attributions. This implies that people blame poor people for their poverty while praising wealthy people for their advantaged position (García-Castro et al., 2021). This meritocratic view of poverty and wealth leads people to increase their internal attributions and to minimise the external barriers that contribute to maintaining socioeconomic differences. This pattern of attributions also causes people not to recognise the usefulness of redistribution policies, as they believe that poor people waste their income (Sainz, Loughnan, et al., 2020), while hard-working, affluent individuals or groups do not deserve to be punished by taking part of their wealth (Sainz, Martínez, Rodríguez-Bailón, et al., 2019).

Finally, we identified an inconsistency between participants' SES and the attribution process. Even though we expected that higher SES would be related to maximising internal attributions and minimising external attributions, this pattern did not emerge in our results. However, we acknowledged that individual perceptions and worldviews are often triggered to a greater extent by ideological orientations than by individual standing. This has been found with similar processes in the literature, such as with classist attitudes (Jordan et al., 2020) or the tendency to dehumanise poor people (Sainz, Martínez, Moya, et al., 2019). Within this process, individuals' economic standing is less relevant than their ideological positioning. 


\section{POVERTY AND WEALTH ATTRIBUTION SCALES}

Thus, our findings seem to be in line with this pattern of results, which has been identified in related issues in the literature.

This project had certain limitations. Firstly, the scales were adapted using a sample of Mexican participants from the general population. This constitutes progress relative to previous research. However, considering the diversity of Spanish-speaking countries and people, it seems necessary to test the factorial structure in a broad, diverse sample that includes geographically distinct samples of Spanish speakers (Lobato et al., 2020). Secondly, our adaptation of these scales used items previously implemented in the original instruments. This is a partial limitation, as we already acknowledged, because certain items no longer applied to the current context. Thus, we eliminated those items the expert judges suggested before collecting our data.

All in all, future studies might focus on exploring people's current lay theories or arguments regarding the causes of poverty and wealth. The appearance of new reasons related to contemporary scenarios such as the economic crisis or the COVID-19 pandemic might play a role in understanding socioeconomic differences. Future studies could also incorporate additional dimensions such as the controllability factor (Weiner et al., 2011), which can be incorporated into the existing internal and external factors for poverty and wealth sources. This will increase the depth of understanding regarding how internal or external factors can be perceived as factors that are permanent (e.g., a lack of intelligence) or that can be modified by individuals in the long term (e.g., being born into poverty).

Redefining the structural dimensions of the scales improves the measurement of these constructs. In short, the revised internal and external poverty and wealth attribution scales constitute a robust renewal of the traditional instruments implemented in the literature that will help to expand research in this area. 
POVERTY AND WEALTH ATTRIBUTION SCALES

\section{References}

Adler, N. E., Epel, E. S., Castellazzo, G., \& Ickovics, J. R. (2000). Relationship of subjective and objective social status with psychological and physiological functioning: Preliminary data in healthy white women. Health Psychology, 19(6), 586-592. https://doi.org/10.1037/0278-6133.19.6.586

Alesina, A., \& La Ferrara, E. (2005). Preferences for redistribution in the land of opportunities. Journal of Public Economics, 89, 897-931. https://doi.org/10.1016/j.jpubeco.2004.05.009

Bobbio, A., Canova, L., \& Manganelli, A. M. (2010). Conservative ideology, economic conservatism, and causal attributions for poverty and wealth. Current Psychology, 29, 222-234. https://doi.org/10.1007/s12144-010-9086-6

Bullock, H. E. (1999). Attributions for poverty: A comparison of middle-class and welfare recipient attitudes. Journal of Applied Social Psychology, 29, 2059-2082. https://doi.org/10.1111/j.1559-1816.1999.tb02295.x

Bullock, H. E., \& Fernald, J. L. (2005). Predicting support for eliminating the dividend tax: The role of framing and attributions for wealth. Analysis of Social Issues and Public Policy, 5, 49-66. https://doi.org/10.1111/j.1530-2415.2005.00055.x

Bullock, H. E., Fraser Wyche, K., \& Williams, W. R. (2001). Media images of the poor. Journal of Social Issues, 57(2), 229-246.

Bullock, H. E., Williams, W. R., \& Limbert, W. M. (2003). Predicting support for welfare policies: The impact of attributions and beliefs about inequality. Journal of Poverty, 7(3), 35-56. https://doi.org/10.1300/J134v07n03_03

Carretero-Dios, H., \& Pérez, C. (2007). Standards for the development and review of instrumental studies: Considerations about test selection in psychological research. International Journal of Clinical and Health Psychology, 7(3), 863-882. 
POVERTY AND WEALTH ATTRIBUTION SCALES

Castillo, J. C., \& Rivera-Gutiérrez, M. (2018). Dimensiones comunes a las atribuciones de pobreza y riqueza [Common dimensions for poverty and wealth attributions]. Psykhe, 27(2), 1-10. https://dx.doi.org/10.7764/psykhe.27.2.1152

CONEVAL. (2018). Medición de la pobreza en México [Measuring poverty in Mexico]. Retrieved from https://www.coneval.org.mx/Medicion/Paginas/PobrezaInicio.aspx

Cozzarelli, C., Wilkinson, A. V., \& Tagler, M. J. (2001). Attitudes toward poor people and attributions for poverty. Journal of Social Issues, 57(2), 207-227. https://doi.org/10.1111/0022-4537.00209

Dawtry, R. J., Sutton, R. M., \& Sibley, C. G. (2015). Why wealthier people think people are wealthier, and why it matters: From social sampling to attitudes to redistribution. Psychological Science, 26, 1389-1400. https://doi.org/10.1177/0956797615586560

Feagin, J. R. (1972). Poverty: We still believe that God helps those who help themselves. Psychology Today, 6(6), 101-110.

Feagin, J. R. (1975). Subordinating the poor: Welfare and American beliefs. Prentice-Hall. Forgas, J. P., Morris, S. L., \& Furnham, A. (1982). Lay explanations of wealth: Attributions for economic success. Journal of Applied Social Psychology, 12(5), 381-397. https://doi.org/10.1111/j.1559-1816.1982.tb00873.x

Furnham, A. (1982). Why are the poor always with us? Explanations for poverty in Britain. British Journal of Social Psychology, 21, 311-322. https://doi.org/10.1111/j.20448309.1982.tb00553.x

García-Castro, J.D., García-Sánchez, E., Montoya-Lozano, M., \& Rodríguez-Bailón, R. (2021). The perception of economic inequality in everyday life: My friends with the most and least money. Asian Journal of Social Psychology. Advance online publication. https://doi.org/10.1111/ajsp.12476 
POVERTY AND WEALTH ATTRIBUTION SCALES

Hambleton, R. K. (2005). Issues, designs, and technical guidelines for adapting tests into multiple languages and cultures. In R. Hambleton, P. Merenda \& S. Spielberger (Eds.), Adapting educational and psychological tests for cross-cultural assessment (pp. 3-38). Lawrence Erlbaum Associates.

Heider, F. (1958). The psychology of interpersonal relations. John Wiley.

Ho, A. K., Sidanius, J., Kteily, N., Sheehy-Skeffington, J., Pratto, F., Henkel, K. E., Foels, R., \& Stewart, A. L. (2015). The nature of social dominance orientation: Theorizing and measuring preferences for intergroup inequality using the new $\mathrm{SDO}_{7}$ scale. Journal of Personality and Social Psychology, 109(6), 1003-1028. https://doi.org/10.1037/pspi0000033

Hunt, M. O. (2004). Race/ethnicity and beliefs about wealth and poverty. Social Science Quarterly, 85, 827-853. https://doi.org/10.1111/j.0038-4941.2004.00247.x

Jaume, L., Etchezahar, E., \& Cervone, N. (2012). La justificación del sistema económico y su relación con la orientación a la dominancia social [The justification of the economic system and its relation to the orientation towards social dominance]. Boletín de Psicología, 106, 81-91.

Jordan, J. A., Lawler, J. R., \& Bosson, J. K. (2021). Ambivalent classism: The importance of assessing hostile and benevolent ideologies about poor people. Basic and Applied Social Psychology, 43(1), 46-67. https://doi.org/10.1080/01973533.2020.1828084

Kelley, H. H. (1967). Attribution theory in social psychology. Nebraska Symposium on Motivation, 15, 192-238.

Kluegel, J. R., \& Smith, E. R. (1986). Beliefs about inequality: Americans' views of what is and what ought to be. Aldine de Gruyter. 
POVERTY AND WEALTH ATTRIBUTION SCALES

Kraus, M. W., \& Keltner, D. (2009). Signs of socioeconomic status: A thin-slicing approach. Psychological Science, 20(1), 99c106. https://doi.org/10.1111/j.14679280.2008.02251.x

Lepianka, D., van Oorschot, W., \& Gelissen, J. (2009). Popular explanations of poverty: A critical discussion of empirical research. Journal of Social Policy, 38, 421-438. https://doi.org/10.1017/S0047279409003092

Furnham, A. (1982). Why are the poor always with us? Explanations for poverty in Britain. British Journal of Social Psychology, 21, 311-322. https://doi.org/10.1111/j.20448309.1982.tb00553.x

Lobato, R. M., Sainz, M., \& García-Sánchez, E. (2020). Adaptation and validation of the Self-Censorship Orientation (SCO) scale into Spanish / Adaptación y validación de la escala de Orientación a la Autocensura (OAC) al español. International Journal of Social Psychology, 35(2), 310-341. https://doi.org/10.1080/02134748.2020.1723367

Nasser, R. (2007). Does subjective class predict the causal attribution for poverty? Journal of Social Sciences, 3(4), 197-201. https://doi.org/10.3844/jssp.2007.197.201

Osborne, D., \& Weiner, B. (2015). A latent profile analysis of attributions for poverty: Identifying response patterns underlying people's willingness to help the poor. Personality and Individual Differences, 85, 149-154. https://doi.org/10.1016/j.paid.2015.05.007

Piurko, Y., Schwartz, S., \& Davidov, E. (2011). Basic personal values and the meaning of left-right political orientations in 20 countries. Political Psychology, 32(4), 537-561. https://doi.org/10.1111/j.1467-9221.2011.00828.x

R Core Team. (2019). R: A language and environment for statistical computing. $\mathrm{R}$ Foundation for Statistical Computing. 
POVERTY AND WEALTH ATTRIBUTION SCALES

Robinson, J. W. (2009). American poverty causes beliefs and structured inequality legitimation. Sociological Spectrum, 29(4), 489-518. https://doi.org/10.1080/02732170902904681

Ross, L. (1977). The intuitive psychologist and his shortcomings: Distortions in the attribution process. In L. Berkowitz (Ed.), Advances in Experimental Social Psychology (pp. 173-220). Academic Press. https://doi.org/10.1016/S0065-2601(08)60357-3

Rosseel, Y. (2012). Lavaan: An R package for structural equation modeling and more. Journal of Statistical Software, 48(2), 1-36.

Sainz, M., Loughnan, S., Martínez, R., Moya, M., \& Rodríguez-Bailón, R. (2020). Dehumanization of socioeconomically disadvantaged groups decreases support for welfare policies via perceived wastefulness. International Review of Social Psychology, 33(1), 1-13. http://doi.org/10.5334/irsp.414

Sainz, M., Martínez, R., Moya, M., \& Rodríguez-Bailón, R. (2019). Animalizing the disadvantaged, mechanizing the wealthy: The convergence of socioeconomic status and humanity attributions. International Journal of Psychology, 54(4), 423-430. https://doi.org/10.1002/ijop.12485

Sainz, M., Martínez, R., Rodríguez-Bailón, R., \& Moya, M. (2019). Where does the money come from? Humanizing high socioeconomic status groups promotes income inequality. Frontiers in Psychology, 10, 711. https://doi.org/10.3389/fpsyg.2019. 00771

Sainz, M., Martínez, R., Sutton, R. M., Rodríguez-Bailón, R., \& Moya, M. (2020). Less human, more to blame: Animalizing poor people increases blame and decreases support for wealth redistribution. Group Processes and Intergroup Relations, 23(4), 546-559. https://doi.org/10.1177/1368430219841135

Satorra, A., \& Bentler, P. M. (2001). A scaled difference chi-square test statistic for moment structure analysis. Psychometrika, 66(4), 507-514. https://doi.org/10.1007/BF02296192 
POVERTY AND WEALTH ATTRIBUTION SCALES

Tabachnick B. G., \& Fidell L. (2013). Using multivariate statistics. Pearson.

Tagler, M. J., \& Cozzarelli, C. (2013). Feelings toward the poor and beliefs about the causes of poverty: The role of affective-cognitive consistency in help-giving. Journal of Psychology: Interdisciplinary and Applied, 147, 517-539. https://doi.org/10.1080/00223980.2012.718721

Watkins, M. W. (2000). Monte Carlo PCA for parallel analysis [computer software]. Ed \& Psych Associates.

Weiner, B., Osborne, D. \& Rudolph, U. (2011). An attributional analysis of reactions to poverty: The political ideology of the giver and the perceived morality of the receiver. Personality and Social Psychology Review, 15, 199-213.

https://doi.org/10.1177/1088868310387615 


\section{POVERTY AND WEALTH ATTRIBUTION SCALES}

Table 1. Original and adapted items of the attribution about poverty (Cozzarelli et al., 2001) and wealth scale (Bullock et al., 2003).

\begin{tabular}{|c|c|}
\hline Original Items of the Attributions about Poverty Scale & Adapted Items of the Attributions about Poverty Scale \\
\hline 1. Prejudice and discrimination in hiring (E) & La discriminación laboral y el prejuicio a la hora de la contratación (E) \\
\hline 2. Failure of industry to provide enough jobs $(\mathrm{E})$ & -- \\
\hline 3. A federal government which is insensitive to the plight of the poor (E) & La insensibilidad del gobierno ante la situación de las personas pobres (E) \\
\hline 4. Prejudice and discrimination in promotion and wages $(\mathrm{E})$ & La discriminación en los salarios y la falta de las oportunidades de ascender laboralmente (E) \\
\hline 5. Being taken advantage of by the rich (E) & La explotación por parte de las personas ricas $(\mathrm{E})$ \\
\hline 6. Not having the right "contacts" to help find jobs (E) & -- \\
\hline 7. Not inheriting money from relatives $(\mathrm{E})$ & -- \\
\hline 8. Lack of effort and laziness by the poor (I) & La falta de esfuerzo y la vagancia (I) \\
\hline 9. No attempts at self-improvement (I) & No intentar mejorar su situación personal (I) \\
\hline 10. Lack of thrift and proper money management (I) & No intentar ahorrar ni administrar adecuadamente el dinero (I) \\
\hline 11. Alcohol and drug abuse (I) & El abuso del alcohol y otras substancias (I) \\
\hline 12. Loose morals among poor people (I) & La falta de principios morales (I) \\
\hline 13. A lack of motivation caused by being on welfare (I) & La falta de motivación para salir adelante causada por recibir ayudas sociales (I) \\
\hline 14. Having to attend bad schools (C) & -- \\
\hline 15. Being born into poverty $(\mathrm{C})$ & -- \\
\hline 16. The types of jobs that the poor can get are often low paying $(\mathrm{C})$ & Los tipos de trabajos a los que pueden acceder generalmente tienen salarios bajos (E) \\
\hline 17. Being born with a low IQ (C) & -- \\
\hline Original Items of the Attributions about Wealth Scale & Adapted Items of the Attributions about Wealth Scale \\
\hline 1. $\quad$ Ambition and personal drive $(\mathrm{P})$ & La ambición y la motivación personal para superarse personalmente (I) \\
\hline 2. Saving money and careful spending $(\mathrm{P})$ & Ahorrar dinero y gastarlo cuidadosamente (I) \\
\hline 3. The economic system makes it possible for individuals to pursue their dreams (P) & -- \\
\hline 4. Being very intelligent $(\mathrm{P})$ & Ser muy inteligente (I) \\
\hline 5. Great ability or talent $(\mathrm{P})$ & Poseer una gran habilidad o talento (I) \\
\hline 6. A willingness to take risks $(\mathrm{P})$ & Estar dispuestas a arriesgarse más para conseguir sus metas (I) \\
\hline 7. Hard work and perseverance $(\mathrm{P})$ & Trabajar duro y ser perseverante (I) \\
\hline 8. Ruthlessness (Co) & -- \\
\hline
\end{tabular}




\section{POVERTY AND WEALTH ATTRIBUTION SCALES}

9. The economic system allows the wealthy to take unfair advantage of the poor (Co)

10. Dishonesty and willingness to take what one can get (Co)

11. The tax system favors the rich (Co)

12. Political influence or "pull" (Co)

13. Networking and having the right "contacts" $(\mathrm{Co})$

14. Investing wisely in the stock market (L)

15. Being born with good business sense (L)

16. Good luck or being in the right place at the right time (L)

17. Winning money from gambling or the lottery $(\mathrm{L})$

18. Attending elite schools and universities $(\mathrm{P})$

19. Better opportunities that result from being born into a well-off family (P)

20. High salaries paid in some professions (P)

21. Inheriting wealth from parents and relatives $(\mathrm{P})$

Tener influencia política que les beneficie (E) Tener las relaciones y los contactos adecuados (E)

Invertir de manera inteligente su dinero (I)

Nacer con un buen olfato para los negocios (I)

Asistir a centros educativos y universidades de gran prestigio (E)

Tener mejores oportunidades al nacer en una familia acomodada (E)

Heredar dinero de familiares $(\mathrm{E})$

Note: $\mathrm{I}=$ Internal factor; $\mathrm{E}=$ External factor; $\mathrm{C}=$ Cultural factor; $\mathrm{P}=$ Perseverance/Ambition; Co = Corruption/Pull; $\mathrm{L}=\mathrm{Luck} / \mathrm{Fatalistic}$; $\mathrm{P}=$ Privilege. 


\section{POVERTY AND WEALTH ATTRIBUTION SCALES}

Table 2

Mean, standard deviation, item-total correlation, and Cronbach's alpha if the item is eliminated, factor loading, and communality for the items of the attributions about poverty scale

Factor loadings

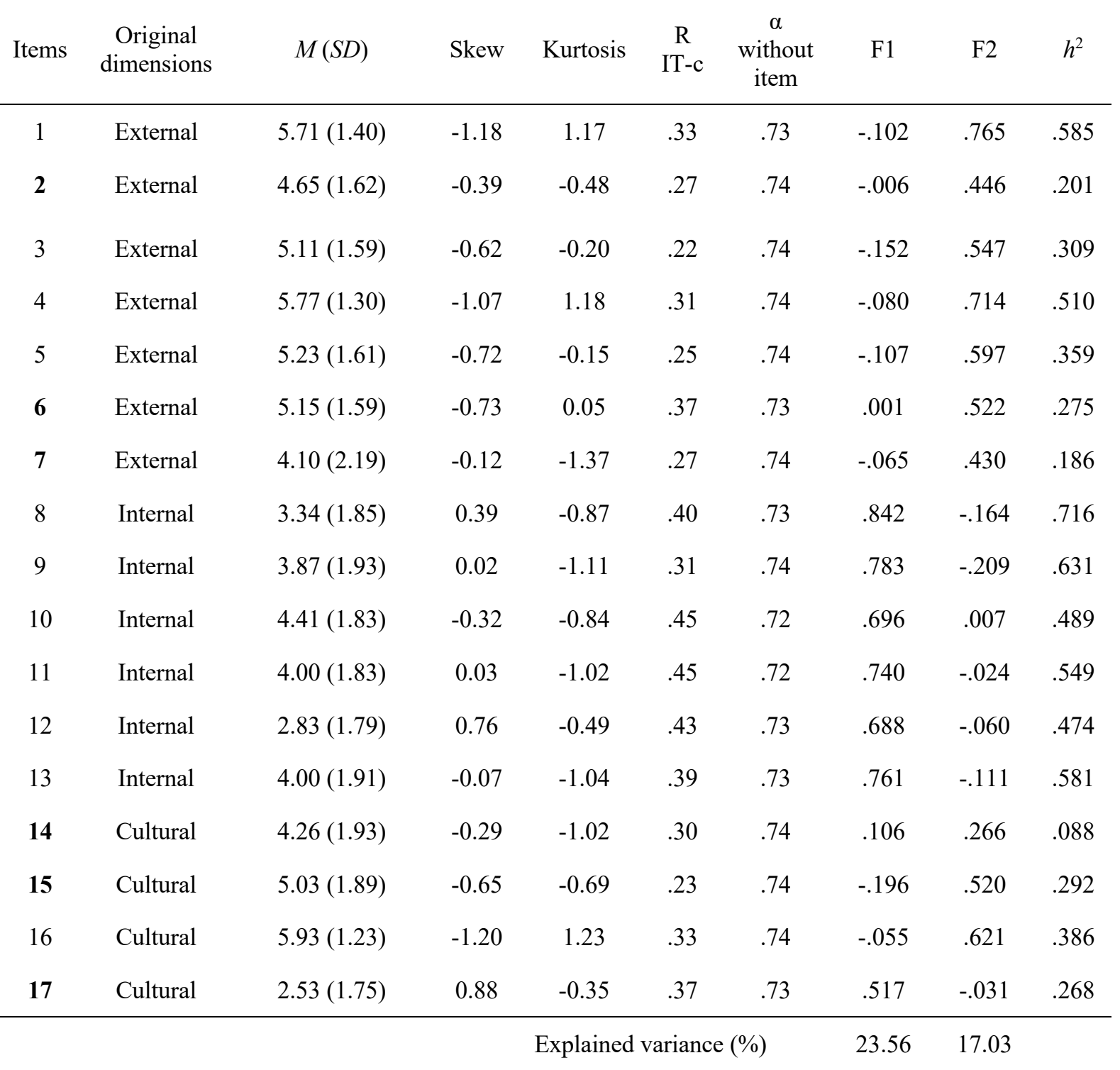

Note: Items in bold were excluded from the scale. 


\section{POVERTY AND WEALTH ATTRIBUTION SCALES}

Table 3

Mean, standard deviation, item-total correlation, and Cronbach's alpha if the item is eliminated, factor loading, and communality for the items of the attributions about wealth scale

Factor loadings

\begin{tabular}{|c|c|c|c|c|c|c|c|c|c|}
\hline \multirow[b]{2}{*}{$\begin{array}{c}\text { Item } \\
\mathrm{s}\end{array}$} & \multirow[b]{2}{*}{$\begin{array}{c}\text { Original } \\
\text { dimensions }\end{array}$} & \multirow[b]{2}{*}{$M(S D)$} & \multirow[b]{2}{*}{ Skew } & \multirow[b]{2}{*}{ Kurtosis } & \multirow[b]{2}{*}{$\begin{array}{c}\mathrm{R} \\
\mathrm{IT}-\mathrm{c}\end{array}$} & \multirow[b]{2}{*}{$\begin{array}{c}\alpha \\
\text { without } \\
\text { item }\end{array}$} & \multicolumn{2}{|c|}{ Factor loadings } & \multirow[b]{2}{*}{$h^{2}$} \\
\hline & & & & & & & $\mathrm{F} 1$ & $\mathrm{~F} 2$ & \\
\hline 1 & Perseverance & $4.85(1.73)$ & -0.63 & -0.39 & .39 & .70 & .761 & -.048 & .581 \\
\hline 2 & Perseverance & 4.77 (1.77) & -0.61 & -0.56 & .35 & .70 & .713 & -.042 & .510 \\
\hline 3 & Perseverance & $4.48(1.91)$ & -0.33 & -0.95 & .21 & .71 & .018 & .257 & .068 \\
\hline 4 & Perseverance & $4.18(1.76)$ & -0.28 & -0.78 & .38 & .70 & .781 & -.092 & 609 \\
\hline 5 & Perseverance & $4.28(1.69)$ & -0.36 & -0.57 & .27 & .71 & .635 & -.175 & .414 \\
\hline 6 & Perseverance & $4.55(1.74)$ & -0.49 & -0.53 & .36 & .70 & .760 & -.114 & .579 \\
\hline 7 & Perseverance & $4.68(1.78)$ & -0.62 & -0.49 & .28 & .71 & .854 & -.236 & .748 \\
\hline 8 & Corruption & $3.64(1.75)$ & 0.12 & -0.97 & .22 & .71 & -.230 & .463 & .245 \\
\hline 9 & Corruption & $5.24(1.66)$ & -0.68 & -0.29 & .13 & .72 & -.381 & .555 & .409 \\
\hline 10 & Corruption & $4.26(1.67)$ & -0.33 & -0.57 & .22 & .71 & -.241 & .485 & .270 \\
\hline 11 & Corruption & $4.99(1.80)$ & -0.66 & -0.52 & -.01 & .73 & -.470 & .415 & .352 \\
\hline 12 & Corruption & $5.66(1.38)$ & -1.04 & 0.59 & .24 & .71 & -.231 & .659 & .458 \\
\hline 13 & Corruption & $6.10(1.18)$ & -1.46 & 2.20 & .38 & .70 & .005 & .621 & .392 \\
\hline 14 & Fatalism & $5.43(1.46)$ & -0.95 & 0.53 & .35 & .70 & .742 & -.074 & .550 \\
\hline 15 & Fatalism & $4.25(1.75)$ & -0.31 & -0.59 & .50 & .69 & .651 & .109 & .459 \\
\hline 16 & Fatalism & $4.55(1.73)$ & -0.38 & -0.58 & .31 & .70 & .130 & .304 & .120 \\
\hline 17 & Fatalismo & $2.12(1.38)$ & 1.41 & 1.89 & .22 & .71 & .063 & .145 & .027 \\
\hline 18 & Privilege & $5.42(1.54)$ & -0.97 & 0.40 & .30 & .70 & -.068 & .564 & .318 \\
\hline 19 & Privilege & $6.11(1.19)$ & -1.64 & 2.96 & .34 & .70 & -.197 & .752 & .578 \\
\hline 20 & Privilege & $5.60(1.34)$ & -0.90 & 0.32 & .31 & .71 & .067 & .460 & .227 \\
\hline 21 & Privilege & $5.79(1.32)$ & -1.17 & 1.29 & .19 & .71 & -.318 & .597 & .419 \\
\hline & & & & Expla & 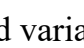 & e $(\%)$ & 26.06 & 13.63 & \\
\hline
\end{tabular}

Note: Items in bold were excluded from the scale. 
POVERTY AND WEALTH ATTRIBUTION SCALES

Table 4

Descriptive statistics and Pearson's bivariate correlations

\begin{tabular}{|c|c|c|c|c|c|c|c|c|c|c|c|c|}
\hline & $M(S D)$ & 1 & 2 & 3 & 4 & 5 & 6 & 7 & 8 & 9 & 10 & $M(S D)$ \\
\hline $\begin{array}{l}\text { 1. Internal } \\
\text { Attribution } \\
\text { s of } \\
\text { Poverty }\end{array}$ & $\begin{array}{c}3.74 \\
(1.48)\end{array}$ & - & $\begin{array}{c}- \\
.22 * \\
* *\end{array}$ & $\begin{array}{l}.59 * \\
* *\end{array}$ & $-.15^{*}$ & $\begin{array}{l}.38 * \\
* *\end{array}$ & $\begin{array}{l}.62 * \\
* *\end{array}$ & $\begin{array}{c}- \\
.23 * \\
* *\end{array}$ & $\begin{array}{l}.26^{*} \\
* *\end{array}$ & $\begin{array}{c}.13 \\
*\end{array}$ & -.07 & $\begin{array}{c}3.64 \\
(1.48)\end{array}$ \\
\hline $\begin{array}{l}\text { 2. External } \\
\text { Attribution } \\
\text { s of } \\
\text { Poverty }\end{array}$ & $\begin{array}{c}5.55 \\
(1.05)\end{array}$ & $-.16^{*}$ & - & $\begin{array}{c}- \\
.21 * \\
*\end{array}$ & $\begin{array}{l}.54 * \\
* *\end{array}$ & $\begin{array}{l}- \\
.49 * \\
* *\end{array}$ & $\begin{array}{c}- \\
.42 * \\
* *\end{array}$ & $\begin{array}{c}.46^{*} \\
* *\end{array}$ & $\begin{array}{c}- \\
.18 * \\
*\end{array}$ & -.09 & .04 & $\begin{array}{c}5.55 \\
(1.12)\end{array}$ \\
\hline $\begin{array}{l}\text { 3. Internal } \\
\text { Attribution } \\
\text { s of Wealth }\end{array}$ & $\begin{array}{c}4.62 \\
(1.33)\end{array}$ & $\begin{array}{l}.60^{*} \\
* *\end{array}$ & $\begin{array}{l}- \\
.25 * \\
* *\end{array}$ & - & $\begin{array}{c}- \\
.19 * \\
*\end{array}$ & $\begin{array}{l}.36^{*} \\
* *\end{array}$ & $\begin{array}{l}.64 * \\
* *\end{array}$ & $\begin{array}{c}- \\
.36 * \\
* *\end{array}$ & $\begin{array}{l}.33 * \\
* *\end{array}$ & $\begin{array}{c}.16 \\
*\end{array}$ & -.07 & $\begin{array}{c}4.46 \\
(1.35)\end{array}$ \\
\hline $\begin{array}{l}\text { 4. External } \\
\text { Attribution } \\
\text { s of Wealth }\end{array}$ & $\begin{array}{c}5.82 \\
(0.98)\end{array}$ & $-.16^{*}$ & $\begin{array}{l}.51^{*} \\
* *\end{array}$ & $\begin{array}{c}- \\
.22 * \\
* *\end{array}$ & - & $\begin{array}{c}- \\
33 * * \\
*\end{array}$ & $\begin{array}{l}- \\
.34 * \\
* *\end{array}$ & $\begin{array}{l}.32 * \\
* *\end{array}$ & $\begin{array}{c}- \\
.20 * \\
*\end{array}$ & -.03 & .09 & $\begin{array}{c}5.82 \\
(0.88)\end{array}$ \\
\hline $\begin{array}{l}\text { 5. Social } \\
\text { Dominance } \\
\text { Orientation }\end{array}$ & $\begin{array}{c}2.60 \\
(1.09)\end{array}$ & $\begin{array}{l}.46^{*} \\
* *\end{array}$ & $\begin{array}{c}- \\
.41^{*} \\
* *\end{array}$ & $\begin{array}{l}.38^{*} \\
* *\end{array}$ & $\begin{array}{c}- \\
.25 * \\
* *\end{array}$ & - & $\begin{array}{l}.51^{*} \\
* *\end{array}$ & $\begin{array}{c}- \\
.38 * \\
* *\end{array}$ & $\begin{array}{l}.34 * \\
* *\end{array}$ & .08 & -.06 & $\begin{array}{c}2.58 \\
(1.03)\end{array}$ \\
\hline $\begin{array}{l}\text { 6. System } \\
\text { Justificatio } \\
n\end{array}$ & $\begin{array}{c}3.99 \\
(1.25)\end{array}$ & $\begin{array}{l}.64 * \\
* *\end{array}$ & $\begin{array}{c}- \\
.33 * \\
* *\end{array}$ & $\begin{array}{l}.63 * \\
* *\end{array}$ & $\begin{array}{c}- \\
.28 * \\
* *\end{array}$ & $\begin{array}{l}.48^{*} \\
* *\end{array}$ & - & $\begin{array}{l}- \\
.40 * \\
* *\end{array}$ & $\begin{array}{l}.34 * \\
* *\end{array}$ & $\begin{array}{l}.19 \\
* *\end{array}$ & -.07 & $\begin{array}{c}3.77 \\
(1.30)\end{array}$ \\
\hline $\begin{array}{l}7 . \\
\text { Redistribut } \\
\text { ion }\end{array}$ & $\begin{array}{c}4.57 \\
(1.45)\end{array}$ & $\begin{array}{l}- \\
.33 * \\
* *\end{array}$ & $\begin{array}{l}.45^{*} \\
* *\end{array}$ & $\begin{array}{l}- \\
.41^{*} \\
* *\end{array}$ & $\begin{array}{l}.28^{*} \\
* *\end{array}$ & $\begin{array}{c}- \\
.50 * \\
* *\end{array}$ & $\begin{array}{c}- \\
.45^{*} \\
* *\end{array}$ & - & $\begin{array}{c}- \\
.41 * \\
* *\end{array}$ & -.05 & .09 & $\begin{array}{c}4.60 \\
(1.37)\end{array}$ \\
\hline $\begin{array}{l}\text { 8. Political } \\
\text { Orientation }\end{array}$ & $\begin{array}{c}3.78 \\
(1.09)\end{array}$ & $\begin{array}{l}.40^{*} \\
* *\end{array}$ & $\begin{array}{c}- \\
.20^{*} \\
*\end{array}$ & $\begin{array}{l}.43^{*} \\
* *\end{array}$ & $-.15^{*}$ & $\begin{array}{l}.25^{*} \\
* *\end{array}$ & $\begin{array}{l}.42 * \\
* *\end{array}$ & $\begin{array}{l}- \\
.36^{*} \\
* *\end{array}$ & - & $\begin{array}{l}.16 \\
*\end{array}$ & $-.14^{*}$ & $\begin{array}{c}3.75 \\
(1.13)\end{array}$ \\
\hline $\begin{array}{l}9 . \\
\text { Subjective } \\
\text { Socioecono } \\
\text { mic Status }\end{array}$ & $\begin{array}{c}5.93 \\
(1.09)\end{array}$ & .12 & -.06 & $.16^{*}$ & -.07 & .07 & $.14^{*}$ & -.01 & .02 & - & $\begin{array}{l}.24 * \\
* *\end{array}$ & $\begin{array}{c}5.81 \\
(1.44)\end{array}$ \\
\hline $\begin{array}{l}10 . \\
\text { Objective } \\
\text { Socioecono } \\
\text { mic Status }\end{array}$ & $\begin{array}{c}16663.4 \\
4 \\
(79555 . \\
56)\end{array}$ & .04 & -.05 & .09 & -.02 & .04 & -.01 & -.09 & .04 & $\begin{array}{l}.13 \\
*\end{array}$ & - & $\begin{array}{c}10457.5 \\
5 \\
(32469 . \\
70)\end{array}$ \\
\hline
\end{tabular}

Note: ${ }^{* * *} p<.001,{ }^{* *} p<.01,{ }^{*} p<.05$; Subsample 1 below the diagonal; Subsample 2 above the diagonal. 